\title{
Enhancing the Psychology Curriculum through Service Learning
}

\author{
Robert G. Bringle \\ Indiana University - Purdue University Indianapolis \\ Ana I. Ruiz \\ Alvernia University \\ Margaret A. Brown \\ Seattle Pacific University \\ Roger N. Reeb \\ University of Dayton
}

\begin{abstract}
Educators in psychology should aspire to encourage students' holistic growth in academic, personal, and civic domains. We propose that service learning is the most potent pedagogy for developing wellrounded, psychologically literate citizens capable of meeting the goals for the undergraduate psychology major. This article defines service learning, delineates the rationales for service learning, and summarizes research demonstrating the efficacy of this pedagogical approach. The article also describes the learning objectives derived from the American Psychological Association Guidelines for the Undergraduate Major (Version 2.0, 2013), with an emphasis on the ways in which service learning contributes to academic learning, civic learning, and personal growth. Finally, the article illustrates the four types of service learning, and it provides a concrete example for structuring reflection in order to connect community experiences with course content in a service learning psychology course.
\end{abstract}

Keywords: Service learning, psychologically literate citizens, reflection, undergraduate psychology curriculum

This is the author's manuscript of the article published in final edited form as:

Bringle, R. G., Ruiz, A. I., Brown, M. A., \& Reeb, R. N. (2016). Enhancing the Psychology Curriculum Through Service Learning. Psychology Learning \& Teaching, 15(3), 294-309.

http://doi.org/10.1177/1475725716659966 
The term "psychologically literate citizen" has been proposed as a descriptor for the model undergraduate psychology major in several countries (Cranney, Botwood, \& Morris, 2012; Halpern, 2010; Harre' , Milfont, Helton, \& Mead, 2011; Job, Lotto, \& Tonzar, 2011; Karandashev, 2011; Mair, Taylor, \& Hulme, 2013; Sarwono, 2011; Trapp et al., 2011). Through a rigorous undergraduate education, students will have attained not only fluency in their knowledge of the field (i.e., psychological literacy), but they will also be compassionate, engaged, and efficacious citizens. McGovern et al. (2010) describe the psychologically literate citizen as "someone who responds to the call for ethical commitment and social responsibility as a hallmark of his or her lifelong liberal learning"' (p. 10). The vision of the psychologically literate citizen provides an important basis for understanding the centrality and value of an education in psychology that fosters civic development, civic learning, and civic outcomes for majors and non-majors. We contend that service learning is the most effective pedagogical tool for psychology educators seeking to develop psychologically literate citizens. This paper will describe service learning, how it can facilitate meeting undergraduate goals such as those proposed by the American Psychological Association (APA), and empirically based rationales for integrating it into the psychology curriculum. We will outline suggestions for incorporating service learning into psychology courses, including an example for designing reflection in order to connect community experiences with course content.

Service learning can be defined as a course-based, credit-bearing educational experience in which students (a) participate in mutually identified and organized service activities that benefit the community, and (b) reflect on the service activity in such a way as to gain further understanding of course content, a broader appreciation of the discipline, and an enhanced sense of personal values and civic responsibility (Bringle \& Clayton, 2012, p. 105; adapted from Bringle \& Hatcher, 1996, p. 222).

This definition notes that service learning involves community service that is integrated into academic courses, unlike volunteering which is co-curricular. The definition acknowledges that service learning 
involves having students and faculty work with community partners in ways in which all can teach, and all can learn (Sigmon, 1979). Thus, partnerships that encompass reciprocity and mutual benefits for all constituencies are central to service learning.

The definition also highlights that regular and structured reflection activities are important in helping students make meaning out of their community-based activities. In this way, reflection treats the community service activities as a "text" that is to be interpreted, analyzed, and connected to other course content, to civic issues, and to their personal growth. Finally, the definition asserts that, in addition to students serving in order to learn (i.e., applied learning), service learning makes a distinctive contribution to learning because it also focuses intentionally on having students consider their "sense of personal values and civic responsibility." Thus, service learning focuses on students learning to serve by having them consider, analyze, and critically examine their role in civic affairs now and in the future.

Altman (1996) proposed that the undergraduate psychology curriculum should support three learning domains: (a) foundational knowledge (i.e., the core content and methods of psychology), (b) professional knowledge (i.e., knowledge of the practice of psychology), and (c) socially responsive knowledge. The purposes of socially responsive knowledge include, "first to educate students in the problems of society; second, have them experience and understand first-hand social issues in their community; and third, give students the experience and skills to act on social problems" (Altman, 1996: pp. 374-375). More recently, the APA Guidelines for the Undergraduate Psychology Major 2.0 (APA, 2103; hereafter referred to as APA Guidelines 2.0) identified five learning goals: (a) knowledge base in psychology, (b) scientific inquiry and critical thinking, (c) ethical and social responsibility in a diverse world, (d) communication, and (e) professional development. The first two APA goals map onto Altman's foundational knowledge, the fourth and fifth goals are most similar to Altman's professional knowledge, and the third APA goal is consistent with Altman's socially responsive knowledge. However, we contend that the psychologically literate citizen is the embodiment of a graduate who is proficient in all of these 
domains. We will use the APA Guidelines 2.0 as a basis for examining and illustrating how service learning can enhance the entire undergraduate psychology curriculum and all of the APA goals. This will serve as a model for how psychology instructors in other national contexts can explore and adapt service learning to enhance their learning goals.

The extant literature on service learning as a component of education in psychology is underdeveloped (Reich \& Nelson, 2010). Bringle and Duffy (1998) examined the role of service learning in the psychology curriculum by offering theoretical analyses and examples of service learning courses. A few other analyses of the role of service learning have occurred in psychology (e.g., Altman, 1996; Chew et al., 2010; McGovern et al., 2010; Osborne \& Renick, 2006; Ozorak, 2004; Reich \& Nelson, 2010). However, most of the authors in the edited volumes Undergraduate education in psychology: A blueprint for the future of the discipline (Halpern, 2010) and The psychologically literate citizen: Foundations and global perspectives (Cranney \& Dunn, 2011) did not mention service learning (exceptions were Charlton \& Lymburner, 2011; Chew et al., 2010; Sokol \& Kuebli, 2011).

In response to this lacuna, Bringle, Reeb, Brown, and Ruiz (2016) offered an extensive analysis of (a) the psychologically literate citizen as an organizing concept for undergraduate education in psychology; (b) a rationale for increasing civic learning and personal growth as explicit and intentional objectives in the undergraduate curriculum; (c) theoretical and empirical explications of service learning's relevance to teaching the science of psychology; (d) a framework for generating service learning course objectives that includes the intersection of APA's five learning goals with the three major learning domains (academic learning, civic learning, and personal growth); (e) examples of integrating community-based activities into a broad range of psychology courses from introductory through major courses to capstone courses; (f) concrete examples of reflection activities that can deepen the connections of community service activities to learning objectives; and (g) guidance for expanding faculty involvement, 
departmental civic engagement, research using service learning, and assessment of and research on service learning. This article is largely based on that work.

\section{Rationales for Service Learning}

Service learning fulfills several different educational agendas (Zlotkowski \& Duffy, 2010), each of which provides a motivational basis for increasing the presence of service learning in psychology courses for both majors and non-majors.

(1) Academic learning: Service learning has been shown to engage students in their studies and enhance disciplinary learning of academic content (Fitch, Steinke, \& Hudson, 2013; Jameson, Clayton, \& Ash, 2013; Novak, Markey, \& Allen, 2007). Furthermore, the psychology curriculum is enriched through community-based service activities that are educationally meaningful. Huber and Hutchings (2010) note, "When faculty from different disciplinary communities teach their fields wearing a civic lens, both the concept of citizenship and even the field itself (as taught and learned) are subject to change" (p. x).

(2) Instructor's role: Consistent with Barr and Tagg's (1995) advocacy for a shift from teaching-oriented approaches of instruction to a learning-oriented approach, service learning changes the role of the instructor from a "sage on the stage" to a facilitator of student learning. Also, it places additional responsibility on students to be active in the learning process through collaboration with community partners and peers. As such, service learning is aligned with Barr and Tagg's recommendation that "a college's purpose is not to transfer knowledge but to create environments and experiences that bring students to discover and construct knowledge ... to make students members of communities of learners that ... solve problems" (p. 4).

(3) Social responsibility: Service learning has students confront social issues, analyze their origins, formulate responses, and engage in advocacy. Thus, service learning provides a means for making 
salient the systemic and structural characteristics of complex social issues facing communities and of marginalized and disadvantaged persons in society. This allows service learning to transcend a charity orientation to service and foregrounds issues related to social justice as a dimension of social responsibility.

(4) Partnerships: Based on the desire to teach democratic values and skills, the nature of partnerships in service learning should encompass democratic values (i.e., fair, inclusive, participatory) (Saltmarsh, Hartley, \& Clayton, 2009) in order for students' democratic skills to be most effectively developed. Examining Dewey's contributions to the intellectual and practical foundations of service learning, Benson, Harkavy, and Puckett (2011) note:

Dewey theorized that education and society were dynamically interactive and interdependent. It followed, therefore, that if human beings hope to develop and maintain a particular type of society or social order, they must develop and maintain the particular type of education system conducive to it; that is to say, if there is no effective democratic schooling system, there will be no democratic society. (p. 52)

(5) Research: Involving students in research in ways that (a) enhance their learning and civicmindedness and (b) advance campus-community research endeavors, especially participatory community action research (PCAR) projects (e.g., Reeb, Glendening, Farmer, Snow, \& Elvers, 2014), can broaden learning outcomes for students. Use of service learning pedagogy to support PCAR projects coincides with the third and fourth rationales noted above, which emphasized opportunities for students to examine social issues, learn democratic values and skills, and engage in advocacy. Minkler and Wallerstein (2003, p. 6) defined PCAR as follows: "A collaborative approach to research that equitably involves all partners ... and recognizes the unique strengths that each brings ... [PCAR] begins with a research topic of importance to the community with the 
aim of combining knowledge and action for social change to improve community." Strand, Cutforth, Stoecker, Marullo, and Donahue (2003) contended that [PCAR], "when used as a teaching strategy, is an exceptionally effective form of service learning ... appropriate for a variety of ... curricular levels"' (p. 137).

(6) Ethics: Service learning provides students with the opportunity to (a) become familiar with the codes of conduct of social agencies where they work, (b) obtain experiences that shape their professional behavior to align with those codes, and (c) recognize the correspondence between such codes and other professional codes (such as the APA (2010) Ethical Principles of Psychologists and Code of Conduct; see Chapdelaine, Ruiz, Warchal, \& Wells, 2005).

(7) Effectiveness: A final rationale for making service learning an expected and pervasive component of the undergraduate psychology curriculum comes from the empirical support that is accumulating about its effectiveness. Reich and Nelson (2010) conclude that, "a ... basic reason for bringing socially responsive knowledge and service learning pedagogy into our curriculum is that in many situations they simply are a more successful way to reach our students" (p. 142). Their conclusion is consistent with empirical analyses identifying service learning as a high impact pedagogy (Kuh, 2008). When examining research that both measured changes across time and research that compared service learning to traditional pedagogies across disciplines, Jameson et al. (2013) reported positive results supporting the efficacy of service learning. Novak et al.'s (2007) meta-analysis found moderate effect sizes favoring service learning for knowledge, grades, and academic motivation; cognitive outcomes had a smaller, but significant effect size favoring service learning. They also found that service learning produced positive and significant effects on personal and citizenship outcomes. Other meta-analyses have supported the conclusion that service learning is positively associated with academic, personal, and civic outcomes, with the effect sizes 
ranging from small through moderate to large (Celio, Durlak, \& Dymnicki, 2011; Conway, Amel, \& Gerwien, 2009; Novak et al., 2007; Warren, 2012; Yorio \& Ye, 2012).

\section{The Psychology Curriculum and Service Learning}

Reich and Nelson (2010) concluded that commitment to service learning in the undergraduate psychology curriculum is not widespread and that most emphasis is still on Altman's foundational knowledge (i.e., APA Guidelines 2.0: goals 1 and 2) rather than on fostering socially responsive knowledge (civic learning) and personal growth (including communication and professional development). When service learning is mentioned in recent literature on the psychology curriculum (Charlton \& Lymburner, 2011; Chew et al., 2010; Sokol \& Kuebli, 2011), it is only aligned with APA goal 3, ethical and social responsibility in a diverse world. This reflects one of the strengths of service learning, but leaves unexplored how service learning can enhance learning associated with a variety of goals, such as the other four proposed by APA. Similarly, personal growth is readily aligned with APA goal 4, communication, and goal 5, professional development. But, again, psychology educators can further explore how personal growth can be aligned with other learning goals. One of the contributions of service learning to the undergraduate curriculum is demonstrating how teaching psychology can benefit from a broader conceptualization of academic learning, civic learning, and personal growth (the three core learning domains, see Figure 1). Table 1 contains an example from Bringle et al. (2016) in which learning objectives in a service learning course have been selected to illustrate the three learning domains combined with the five APA goals. This suggests to educators that experiences can be designed for students in which each one of the five goals and many of their subordinate indicators can have civic dimensions and contribute to personal growth, in addition to foundational, academic knowledge. When this is done, the empirical evidence supports the recommendation that service learning may be the best means for reaching this broader array of learning objectives. 


\section{Four Types of Service Learning}

Four types of service learning have been identified (e.g., Bringle et al., 2016; Florida Department of Education, 2009). First, with direct service learning, students interact with clients at a community agency or with residents in a neighborhood. Examples include assisting clients at a mental health center or homeless shelter, tutoring elementary students in a school, or providing social support to elderly persons in a nursing home. Second, indirect service learning involves students working behind the scenes to improve, expand, or coordinate resources for a community agency or neighborhood association. Examples include fundraising or developing resource materials (e.g., brochures, instructional aids, web design, or enhancing collaborative connections among agencies). Third, students in research service learning use psychological methods to collect, manage, or analyze data. Developing a survey or other instrument, conducting a program evaluation, or managing a data set are common examples. Fourth, in advocacy service learning, students apply psychological theory and research to explore underlying causes of a sociopolitical concern and/or facilitate transformative changes. Examples include conducting presentations to increase public awareness of an issue, advocating for rights of clients or marginalized persons, examining public policy, improving infrastructure in order to enhance access to resources, or lobbying (e.g., telephone calls, emails, letters, or face-to-face meetings) government representatives.

Table 2 illustrates examples of the different types of service learning for a Health Psychology course, organized around the theme of improving health care access for persons experiencing homelessness (from Bringle et al., 2016). Decisions about which type of community service to utilize must take into account the learning objectives of the course, the educational background of the students, the goals of the community partner, and the resources available. Table 2 also illustrates that, in some cases, different types of service learning may occur concurrently at a site, either in the same course or for multiple courses at the same site. Reeb et al. (2014) provide an example of a PCAR project that 
concurrently incorporates all four types of service learning in complementary ways and provides students with opportunities to continue to be involved across sequences of courses.

\section{Reflection and Assessment}

Reaching selected learning objectives through service learning is most likely to occur when there is regular, structured reflection that enhances the educational meaning of community experiences. Bringle et al. (2016) list numerous examples of service learning reflection exercises across a variety of courses in the undergraduate psychology curriculum using the DEAL (Describe, Examine, and Articulate Learning) model for critical reflection (Ash \& Clayton, 2004; Ash \& Clayton, 2009a, 2009b; Jameson, Clayton, \& Bringle, 2008). The DEAL model incorporates the following steps in critical reflection: (a) describe the experiences in detail, (b) examine the experiences from personal, civic, and/or academic perspectives, and (c) articulate learning that has resulted. In the examine stage of DEAL, the prompts (e.g., for written reflection, for group discussion) can be specific learning objectives derived from the APA Guidelines 2.0 with respect to academic learning, civic learning, and/ or personal growth. One tool that is available for writing examine prompts and that facilitates assessment is Bloom's (1956) taxonomy. This approach to reflection provides authentic evidence of the degree to which learning outcomes occur for students and their products can be evaluated using Bloom's taxonomy.

Table 3 provides an example (from Bringle et al., 2016) of how reflection can be structured using the DEAL model and Bloom's taxonomy. For example, if students in an introductory psychology course were tutoring in the public schools, then this assignment would be given for the chapter on learning. This is an example of one reflection assignment for connecting content from the learning chapter to facilitate academic learning, civic learning, and personal growth (note that only some of Bloom's levels may apply to a reflection assignment depending on the goal of the assignment and level of the class). Additional reflection activities would be constructed for other chapters in the course (e.g., development, 
personality, social psychology; see Bringle et al., 2016 for other examples of reflection in more psychology courses).

Good reflection can occur before, during, and after the service activities and can result in students generating new learning and capturing their learning for assessment (Ash \& Clayton, 2009a, 2009b;

Bringle et al., 2016). An assessment plan should match the learning goals established for the course. The assessment may be based on traditional methods (i.e., examinations) as well as other approaches (selfreport scales, APA guidelines 2.0 recommendations for assessment, DEAL model, and Bloom's taxonomy). Assessment can include as many of the community partners involved in the service as possible and contribute to student learning through feedback given to students.

\section{Conclusion}

The APA Guidelines 2.0 are but one example for how the goals for the psychology curriculum can be articulated. Those in other contexts can similarly articulate their goals and determine how service learning and other high impact teaching practices can optimize reaching those goals. Serving in communities provides the opportunity to confront ill-defined situations and can spur students to consider how communities work and how psychological content can help them better understand diverse community members and themselves. Through service learning, students are exposed to critical civic issues and the ways that they can make a contribution to the public good. A growing body of research leads to the conclusion that service learning provides clear "value added" for reaching learning outcomes and producing psychologically literate citizens. The science of teaching and learning as evidence-based practice (Terry, Smith, \& McQuillin, 2014) demonstrates service learning's capacity to augment academic learning, civic learning, and personal growth of students, and should attract attention amongst all serious scholar-educators in psychology. See Bringle et al. (2016) for a more 
extensive analysis of service learning in the psychology curriculum and concrete examples for various courses in the curriculum.

In her analysis of the role of Thorndike and Dewey in higher education, Langemann (1989) concluded, "I have often argued to students, only in part to be perverse, that one cannot understand the history of education in the United States during the twentieth century unless one realizes that Edward L. Thorndike won and John Dewey lost" (p. 185). Dewey's emphasis was on community praxis for developing rationally, morally, and civically grounded students, whereas Thorndike's focus was on the quantification of learning, intellectual achievement, and the perspective that there is an inevitable and meaningful societal hierarchy based on intellectual and academic superiority (Lightfoot, 2013). In line with Dewey, and consistent with the ideal of developing psychologically literate citizens (Halpern, 2010; McGovern et al., 2010), we contend that the role of civic education in the psychology curriculum is crucial and warrants an adjustment to increase its salience through service learning. High quality service learning in psychology is predicated on democratic community partnerships to use developmentally appropriate opportunities for critical reflection. This method of designing and implementing service learning is the most powerful way of engaging both majors and nonmajors in their academic work and developing students' civic identity that is anchored within the psychological curriculum (Bringle, Clayton, \& Bringle, 2015).

\section{Declaration of Conflicting Interests}

The author(s) declared no potential conflicts of interest with respect to the research, authorship, and/or publication of this article.

\section{Funding}

The author(s) received no financial support for the research, authorship, and/or publication of this article. 


\section{References}

Altman, I. (1996). Higher education and psychology in the millennium. American Psychologist, 51, 371378. doi: 10.1037/0003-066X.51.4.371

American Psychological Association (2010). Ethical principles of psychologists and code of conduct.

Washington, DC: American Psychological Association.

American Psychological Association. (2013). APA guidelines for the undergraduate psychology major: Version 2.0. Retrieved from http://www.apa.org/ed/precollege/undergrad/index.aspx

Ash, S. L., \& Clayton, P. H. (2004). The articulated learning: An approach to guided reflection and assessment. Innovative Higher Education, 29(2), 137-154.

Ash, S. L., \& Clayton, P. H. (2009a). Generating, deepening, and documenting learning: The power of critical reflection for applied learning. Journal of Applied Learning in Higher Education, 1, 25-48.

Ash, S. L., \& Clayton, P. H. (2009b). Learning through critical reflection: A tutorial for students in servicelearning (Instructor version). Raleigh, NC: Authors.

Barr, R. B., \& Tagg, J. (1995). From teaching to learning: A new paradigm for undergraduate education. Change, 27(6), 13-25.

Benson, L., Harkavy, I., \& Puckett, J. (2011). Democratic transformation through university-assisted community schools. In J. Saltmarsh \& M. Hartley (Eds.), To service a larger purpose: Engagement for democracy and the transformation of higher education (pp. 50-81). Philadelphia: Temple University Press.

Bloom, B. S. (Ed.). (1956). Taxonomy of educational objectives, handbook I: Cognitive domain.

New York, NY: David McCay. 
Bringle, R. G., \& Clayton, P. H. (2012). Civic education through service-learning: What, how, and why? In L. Mcllrath, A. Lyons \& R. Munck (Eds.), Higher education and civic engagement: Comparative perspectives (pp. 101-124). New York, NY: Palgrave.

Bringle, R. G., Clayton, P. H., \& Bringle, K. E. (2015). Teaching democratic thinking is not enough: The case for democratic action. Partnerships: A Journal of Service Learning \& Civic Engagement, 6(1), 1-26.

Bringle, R. G., \& Duffy, D. K. (Eds.) (1998). With service in mind: Concepts and models for service learning in psychology. Washington, DC: American Association for Higher Education.

Bringle, R. G., \& Hatcher, J. A. (1996). Implementing service learning in higher education. Journal of Higher Education, 67, 221-239.

Bringle, R. G., Reeb, R., Brown, M. A., \& Ruiz, A. I. (2016). Service learning in psychology: Enhancing undergraduate education for the public good. Washington, DC: American Psychological Association.

Celio, C. I., Durlak, J., \& Dymnicki, A. (2011). A meta-analysis of the impact of service-learning on students. Journal of Experiential Education, 34, 164-181.

Chapdelaine, A., Ruiz, A., Warchal, J., \& Wells, C. (2005). Service-learning code of ethics. Boston, MA: Anker.

Charlton, S., \& Lymburner, J. (2011). Fostering psychologically literate citizens: A Canadian perspective. In J. Cranney \& D. S. Dunn (Eds.), The psychologically literate citizen: Foundations and global perspectives (pp. 234-248). New York, NY: Oxford University Press.

Chew, S. L., Bartlett, R. M., Dobbins, J. E., Hammer, E. Y., Kite, M. E., Loop, T. F., McIntryre, J. G., \& Rose, K. C. (2010). A contextual approach to teaching: Bridging methods, goals, and outcomes. In D. F. Halpern (Ed.), Undergraduate education in psychology: A Blueprint for the future of the discipline (pp. 95-112). Washington, DC: American Psychological Association. 
Conway, J. M., Amel, E. L., \& Gerwien, D. P. (2009). Teaching and learning in the social context: A metaanalysis of service learning's effects on academic, personal, social, and citizenship outcomes. Teaching of Psychology, 36, 233-245. doi: 10.1080/00986280903172969

Cranney, J., Botwood, L. \& Morris, S. (2012). National standards for psychological literacy and global citizenship: Outcomes of undergraduate psychology education. Sydney, NSW: Office for Learning and Teaching. Retrieved from https://groups.psychology.org.au/Assets/Files/Cranney NTF

\section{Final Report 231112 Final pdf.pdf}

Cranney, J., \& Dunn, D. (Eds.). (2011). The psychologically literate citizen: Foundations and global perspectives. New York, NY: Oxford University Press.

Fitch, P., Steinke, P., \& Hudson, T. D. (2013). Research and theoretical perspectives on cognitive outcomes of service learning. In P. H. Clayton, R. G. Bringle \& J. A. Hatcher (Eds.), Research on service learning: Conceptual frameworks and assessment. Volume 2A: Students and faculty (pp. 57-84). Arlington, VA: Stylus.

Florida Department of Education (2009). Standards for service-learning in Florida: A guide for creating and sustaining quality practice. Tallahassee, FL: Florida Learn \& Serve.

Halpern, D. F. (Ed.) (2010) Undergraduate education in psychology: A blueprint for the future of the discipline. Washington, DC: American Psychological Association.

Harre' , N., Milfont, T. L., Helton, W., \& Mead, A. (2011). Sustainability and the psychologically literate citizen: A New Zealand perspective. In J. Cranney \& D. S. Dunn (Eds.), The psychologically literate citizen: Foundations and global perspectives (pp. 220-233). New York, NY: Oxford University Press doi:10.1093/acprof:oso/9780199794942.003.0057 
Huber, M. T., \& Hutchings, P. (2010). Foreword. In M. B. Smith, R. S. Nowacek \& J. L. Bernstein (Eds.), Citizenship across the curriculum (pp. ix-xiii). Bloomington, IN: Indiana University Press. Jameson, J. K., Clayton, P. H., \& Ash, S. L. (2013). Conceptualizing, assessing, and investigating academic learning in service learning. In P. H. Clayton, R. G. Bringle \& J. A. Hatcher (Eds.),

Research on service learning: Conceptual frameworks and assessment. Volume 2A: Students and faculty (pp. 85-110). Arlington, VA: Stylus.

Jameson, J. K., Clayton, P. H., \& Bringle, R. G. (2008). Investigating student learning within and across linked service-learning courses. In M. A. Bowdon, S. H. Billig, \& B. A. Holland (Eds.), Advances in servicelearning research: Scholarship for sustaining service-learning and civic engagement (pp. 3-27). Greenwich, CN: Information Age Publishing.

Job, R., Lotto, L., \& Tonzar, C. (2011). Psychological literacy: An Italian perspective. In J. Cranney \& D. S. Dunn (Eds.), The psychologically literate citizen: Foundations and global perspectives (pp. 167-177). New York, NY: Oxford University Press doi:10.1093/acprof:oso/9780199794942. 003.0044

Karandashev, V. (2011). Psychological literacy goals in psychology teaching in Russian education. In J. Cranney \& D. S. Dunn (Eds.), The psychologically literate citizen: Foundations and global perspectives (pp. 206-219). New York, NY: Oxford University Press doi:10.1093/acprof:oso/ 9780199794942.003 .0055

Kuh, G. D. (2008). High-impact educational practices: What they are, who has access to them, and why they matter. Washington, DC: Association of American Colleges and Universities.

Langemann, E. C. (1989). The plural worlds of educational research. History of Education, 29, 185-214. Lightfoot, C. (2013). Educating global citizens: The psychology classroom as seedbed for civil society. Presentation at the National Institute for the Teaching of Psychology, Tampa, FL. 
Mair, C., Taylor, J., and Hulme, J. (2013). An introductory guide to psychological literacy and psychologically literate citizenship. York, UK: Higher Education Academy. Retrieved from https://www. heacademy.ac.uk/sites/default/files/resources/psychological literacy and psychologically literate citizenship.pdf

McGovern, T. V., Corey, L., Cranney, J., Dixon, W. E. Jr, Holmes, J. D., Kuebli, J. E., Ritchey, K. A., Smith, R. A., \& Walker, S. J. (2010). Psychologically literate citizens. In D. F. Halpern (Ed.), Undergraduate education in psychology: A blueprint for the future of the discipline (pp. 9-27). Washington, DC: American Psychological Association.

Minkler, M., \& Wallerstein, N. (2003). Community-Based Participatory Research for Health. San Francisco: Jossey-Bass.

Novak, J. M., Markey, V., \& Allen, M. (2007). Evaluating cognitive outcomes of service learning in higher education: A meta-analysis. Communication Research Reports, 24(2), 149-157.

Osborne, R. E., \& Renick, O. (2006). Service learning. In W. Buskist \& S. F. Davis (Eds.), Handbook of the teaching of psychology (pp. 137-141). Malden, MA: Blackwell Publishers.

Ozorak, E. W. (2004). Integrating service learning into psychology courses. In B. Perlman,

L. I. McCann \& S. H. McFadden (Eds.), Lessons learned: Practical advice for the teaching of psychology (Vol 2, pp. 137-146). Washington, DC: American Psychological Society.

Reeb, R. N., Glendening, Z. S., Farmer, C. N., Snow, N. L., \& Elvers, G. C. (2014). Behavioral activation in a homeless shelter: An interdisciplinary service-learning community-based research project. Paper presented at the annual meeting of the International Association for Research on Service-learning and Community Engagement, New Orleans, LA.

Reich, J. N., \& Nelson, P. D. (2010). Engaged scholarship: Perspectives from psychology. In H. 
E. Fitzgerald, C. Burack \& S. D. Seifer (Eds.), Handbook of engaged scholarship: Contemporary landscapes, future directions. Volume 2: Community-Campus partnerships (pp. 131-147). East Lansing, MI: Michigan State University Press.

Saltmarsh, J., Hartley, M., \& Clayton, P. (2009). Democratic engagement white paper. Boston, MA: New England Resource Center for Higher Education.

Sarwono, S. W. (2011). An Indonesian perspective on psychological literacy. In J. Cranney \& D. S. Dunn (Eds.), The psychologically literate citizen: Foundations and global perspectives (pp. 178-190). New York, NY: Oxford University Press doi:10.1093/acprof:oso/9780199794942.003.0046

Sigmon, R. (1979). Service-learning: Three principles. Synergist, 8, 9-11.

Sokol, B. W., \& Kuebli, J. E. (2011). Psychological literacy: Bridging citizenship and character. In J. Cranney \& D. S. Dunn (Eds.), The psychologically literate citizen: Foundations and global perspectives (pp. 269-280). New York, NY: Oxford University Press.

Strand, K. J., Cutforth, N., Stoecker, R., Marullo, S., \& Donohue, P. (2003). Community-based research and higher education: Principles and practices. San Francisco, CA: Jossey-Bass.

Terry, J. D., Smith, B. H., \& McQuillin, S. D. (2014). Teaching evidence-based practice in servicelearning: A model for education and service. Journal on Excellence in College Teaching, 25(1), 55-69.

Trapp, A., Banister, P., Ellis, J., Latto, R., Miell, D. and Upton, D. (2011). The future of undergraduate psychology in the United Kingdom. York, UK: Higher Education Academy. Retrieved from: http:// www.heacademy.ac.uk/resources/detail/subjects/psychology/Future-undergrad-psych-uk

Warren, J. L. (2012). Does service-learning increase student learning?: A meta-analysis. Michigan Journal of Community Service Learning, Spring, 56-61. 
Yorio, P. L., \& Ye, F. (2012). A meta-analysis on the effects of service-learning on the social, personal, and cognitive outcomes of learning. Academy of Management Learning \& Education, 11(1), 9-27.

Zlotkowski, E., \& Duffy, D. K. (2010). Two decades of community-based learning. In M. C. Svinicki \& C. M. Wehlburg (Eds.), Landmark issues in teaching and learning: A look back at New Directions for Teaching and Learning (Vol 123, pp. 33-43). San Francisco: Jossey-Bass doi:10.1002/tl.407 


\section{Author biographies}

Robert G. Bringle (B.A., Hanover College; M.S., Ph.D., Social Psychology, University of MassachusettsAmherst) is the Kulynych/Cline Visiting Distinguished Professor of Psychology at Appalachian State University; Chancellor's Professor Emeritus of Psychology and Philanthropic Studies, and Senior Scholar, Center for Service and Learning at Indiana University-Purdue University Indianapolis. From 1994 to 2012, he served as Executive Director of the IUPUI Center for Service and Learning. He published With service in mind: Concepts and models for service-learning in psychology (with D. Duffy), The measure of service learning, (with M. Phillips \& M. Hudson), International service learning (with J. Hatcher \& S. Jones), and Research on service learning: Conceptual frameworks and assessment. Vol. 2A: Students and faculty, and Vol. 2B: Communities, institutions, and partnerships (with P. Clayton \& J. Hatcher). Dr. Bringle received the Thomas Ehrlich Faculty Award for Service Learning, the IUPUI Chancellor's Award for Excellence in Teaching, and the Legacy of Service Award from Indiana Campus Compact. In 2004, he was recognized at the International Service-Learning Research Conference for his outstanding contributions to the service-learning research field. The University of the Free State, South Africa, awarded him an honorary doctorate for his scholarly work on civic engagement and service learning.

Ana I. Ruiz (B.S., Catholic University of Pernambuco, Brazil; M.A., Cognitive Development, Federal University of Pernambuco, Brazil; Ph.D., Developmental Psychology, Cornell University; Wye Faculty Seminar, Aspen Institute) is a Professor of Psychology at Alvernia University. Her publications include the book Service-learning code of ethics, chapters and articles on ethical issues on international service learning and research on international service learning, the impact of service on alumni career development, and teaching ethics to undergraduate psychology students. She is the co-creator of the online resource Teaching Ethics to Undergraduate Psychology Students. She has successfully completed 
service learning projects in several undergraduate psychology courses, served on several ethics boards, and consulted on adoption and implementation of service learning.

Margaret A. Brown (B.S., University of Washington; M.S., Ph.D., Social Psychology, University of Washington) is an Associate Professor of Psychology at Seattle Pacific University. She is an experienced service learning practitioner and has won multiple awards for excellence in teaching, including the Distinguished Teaching Award from the University of Washington and the endowed Patricia M. Bentz Teacher of the Year Award from Seattle Pacific University. She was recently nominated by her institution for the CASE/ Carnegie Foundation's U.S. Professor of the Year Award. In addition, she is the recipient of a National Science Foundation fellowship. Dr. Brown's research interests are in self psychology, and in the intersection of prosocial behavior and intergroup relations. She is the author of numerous journal articles, book chapters, and a co-authored text on self-psychology, and has conducted rigorous theorybased, experimental research on service learning. Her examinations of service learning as a form of counter-normative helping behavior reveal its impact on social justice attitudes. This line of research has also identified multiple mediators and moderators of this relationship, such as empathy, generosity, and intergroup contact.

Roger N. Reeb (A.A., Butler County Community College; B.A., Westminster College; M.S., Developmental Psychology, Ph.D., Clinical Psychology, Virginia Commonwealth University; Pre-Doctoral Internship Certificate, Brown University) is Professor of Psychology and Roesch Endowed Chair in the Social Sciences at University of Dayton. At this institution, he served as Director of Graduate Programs in Psychology (2006-2014), received awards (Alumni Award in Teaching, 2012; Outstanding Faculty Service-Learning Award, 1997; Service-Learning Faculty Research Award, 1998), and was nominated for 
the National Ehrlich Faculty Award for Service Learning (1998). From the American Psychological Association, he received the Dissertation Award (1991) and the Springer Award for Excellence in Research in Rehabilitation Psychology (Division 22) (1994). His research focuses on homelessness, psychopathology, and service learning outcomes for students and community. With approximately 30 publications and 80 conference presentations, he published Community action research: Benefits to community members and service providers (2006), edited a service learning research section for American Journal of Community Psychology (2010), and developed the Community service self-efficacy scale. He serves on numerous Editorial Boards (e.g., Michigan Journal of Community Service Learning). As a licensed clinical psychologist, he serves on the Homeless Solutions Board and the National Alliance on Mental Illness Board (Montgomery County, Ohio). 
Table 1. Framework for Generating Learning Objectives for a Service Learning Course from APA Guidelines 2.0

\begin{tabular}{|c|c|c|c|c|c|}
\hline $\begin{array}{l}\text { APA Goals Service } \\
\text { Learning }\end{array}$ & Knowledge base & $\begin{array}{l}\text { Scientific method and } \\
\text { critical thinking }\end{array}$ & $\begin{array}{l}\text { Ethical and social } \\
\text { responsibility in a } \\
\text { diverse world }\end{array}$ & Communication & Professional development \\
\hline Academic learning & $\begin{array}{l}\text { Goal I.2a: Use basic psy- } \\
\text { chological termin- } \\
\text { ology, concepts, and } \\
\text { theories in psychology } \\
\text { to explain behavior } \\
\text { and mental processes. }\end{array}$ & $\begin{array}{l}\text { Goal } 2.1 \text { c: Use an appro- } \\
\text { priate level of com- } \\
\text { plexity to interpret } \\
\text { behavior and mental } \\
\text { processes }\end{array}$ & $\begin{array}{l}\text { Goal 3.3E: Apply psycho- } \\
\text { logical principles to a } \\
\text { public policy issue and } \\
\text { describe the antici- } \\
\text { pated institutional } \\
\text { benefit or societal } \\
\text { change. }\end{array}$ & $\begin{array}{l}\text { Goal } 4.3 \text { b: Recognize that } \\
\text { culture, values, and } \\
\text { biases may produce } \\
\text { misunderstandings in } \\
\text { communication. }\end{array}$ & $\begin{array}{l}\text { Goal 5.ID: Apply relevant } \\
\text { psychology content } \\
\text { knowledge to facilitate } \\
\text { a more effective } \\
\text { workplace in intern- } \\
\text { ships, jobs, or organ- } \\
\text { izational leadership } \\
\text { opportunities. }\end{array}$ \\
\hline Civic learning & $\begin{array}{l}\text { Goal I.3A: Articulate } \\
\text { how psychological } \\
\text { principles can be used } \\
\text { to explain social issues, } \\
\text { address pressing soci- } \\
\text { etal needs, and inform } \\
\text { public policy. }\end{array}$ & $\begin{array}{l}\text { Goal 2.5D: Evaluate the } \\
\text { generalizability of spe- } \\
\text { cific findings based on } \\
\text { parameters of the } \\
\text { research design, } \\
\text { including caution in } \\
\text { extending western } \\
\text { constructs } \\
\text { inappropriately. }\end{array}$ & $\begin{array}{l}\text { Goal 3.3B: Develop psy- } \\
\text { chology-based strate- } \\
\text { gies to facilitate social } \\
\text { change to diminish } \\
\text { discrimination } \\
\text { practices. }\end{array}$ & $\begin{array}{l}\text { Goal 4.3C: Interact sensi- } \\
\text { tively with people of } \\
\text { diverse abilities, back- } \\
\text { grounds, and cultural } \\
\text { perspectives. }\end{array}$ & $\begin{array}{l}\text { Goal 5.IE: Adapt infor- } \\
\text { mation literacy skills } \\
\text { obtained in the psych- } \\
\text { ology major to inves- } \\
\text { tigating solutions to a } \\
\text { variety of problem } \\
\text { solutions. }\end{array}$ \\
\hline Personal growth & $\begin{array}{l}\text { Goal I.3d: Predict how } \\
\text { individual differences } \\
\text { influence beliefs, } \\
\text { values, and inter- } \\
\text { actions with others, } \\
\text { including the potential } \\
\text { for prejudicial and dis- } \\
\text { criminatory behavior }\end{array}$ & $\begin{array}{l}\text { Goal } 2 . \text { IE: Use strategies } \\
\text { to minimize commit- } \\
\text { ting common fallacies } \\
\text { in thinking that impair } \\
\text { accurate conclusions } \\
\text { and predictions. }\end{array}$ & $\begin{array}{l}\text { Goal 3.3c: Explain how } \\
\text { psychology can pro- } \\
\text { mote civic, social, and } \\
\text { global outcomes that } \\
\text { benefit others. }\end{array}$ & $\begin{array}{l}\text { Goal 4.2b: Deliver brief } \\
\text { presentations within } \\
\text { appropriate con- } \\
\text { straints (e.g., time } \\
\text { limit, appropriate to } \\
\text { audience). }\end{array}$ & $\begin{array}{l}\text { Goal 5.4d: Assess } \\
\text { strengths and weak- } \\
\text { nesses in performance } \\
\text { as a project team } \\
\text { member. }\end{array}$ \\
\hline
\end{tabular}

Note. Adapted from Service learning in psychology: Enhancing undergraduate education for the public good (Pp. 62-63), by R. G. Bringle, R. M. Reeb, M. A. Brown, and A. I. Ruiz, 20I6, Washington, DC: American Psychological Association. Reprinted with permission 
Table 2. Examples of Service-Learning Projects in Health Psychology

\begin{tabular}{|c|c|}
\hline & $\begin{array}{l}\text { Type of } \\
\text { service-learning }\end{array}$ \\
\hline
\end{tabular}

Improve health care access for people Direct experiencing homelessness
Indirect

Research

Advocacy
Provide direct assistance to individuals in a homeless shelter to educate them on health care options and health care access.

Develop educational materials for a homeless shelter regarding health care options and access.

Assist with research examining the efficacy of a program that connects clients at a homeless shelter to health care access.

Assist a non-profit organization to influence local, state, or national decisions affecting health care access. Examples of organizations include: Community

Catalyst; Families USA; Health Care for America Now; Enroll America.
Work one-on-one with shelter guests to

(a) explain the Affordable Care Act and Medicaid Expansion or (b) teach them computer skills to access these programs.

Develop materials (brochures or media) or arrange guest speakers to educate clients on (a) the Affordable Care Act and Medicaid Expansion, (b) how to apply for these programs, or (c) how to access health resources (e.g., free clinics) in their own community.

Collaborate with staff to determine (a) the extent to which clients participate in the program and (b) if the program is effective in connecting clients to services, analyze data, and write summaries to disseminate findings to different audiences (including shelter staff).

Assist non-profit organization in educating the public (e.g., presentations), community organizing, or lobbying (e.g., letters to local shelters, Homeless

Solutions Boards, or state representatives) to advocate for (a) resources to improve health care access in shelters or (b) extend a successful model to other shelters. 
Table 3. Sample DEAL Model Reflection Prompt

Learning domain

APA learning outcome

Course-specificlearning objective

DEAL/describe

(objectively...)

DEAL/examine (Six levels are based on Bloom's Taxonomy)

DEAL/articulate learning
Academic Learning, Civic Learning, and Personal Growth (Section 7 of Venn Diagram in Figure I)

Indicator I. Ia: "Use basic psychological terminology, concepts, and theories in psychology to explain behavior and mental processes" (APA, 2013, p. 18).

Students will accurately identify and use terminology, concepts, and theories from the learning chapter with reference to their community activities and their own lives.

- When did these experiences take place? Where did they take place?

- Who else was there? Who wasn't there?

- What did you do? What did others do? What actions did you/others take? What did you/they communicate?

- Who didn't speak or act? Did you/others laugh, cry, make a face, complain, criticize, argue, etc.?

Knowledge: Identify key concepts, theories, and research results from the learning chapter that are relevant to your community service activities at the public school.

Comprehension: Describe each of these elements in your own words so that someone not familiar with psychology can understand each of them.

Application: Identify the connections between each of these elements and your community service activities. How did you observe each of them occurring and who demonstrated the learning element (e.g., by the teacher, by students, by yourself)? Give multiple examples. How do you think each of these elements applies your own behavior in the school (i.e., how have you used these elements)? Give multiple examples.

Analysis: Which of these elements is most relevant to your activities at the public school? What are the similarities and differences between the application of these elements to elementary school students and to you as a college student? Identify circumstances in the elementary students' lives that complicate or inhibit their performance in school. Do the same for yourself.

Synthesis: Which elements might you use in the future to obtain better results from your community activities? Which of these might you use to improve your own performance at the school or your behavior as a college student? Based on your analysis of the role of these elements in how elementary students learn and perform, what changes will you make in your work with them? With the teacher? What positive and negative outcomes might occur if you make these changes? How might learning principles be used to increase parental involvement in their elementary students' school work? What recommendations would you make to college students who work at this school in the future? What changes might you make in your studying based on learning theory? Describe how assisting elementary students has helped you study better. How might you design a self-improvement program for yourself based on learning theory? What do you think the results would be if you implemented such a program? What are the impediments to you implementing a program based on learning principles to improve your studying?

Evaluation: What do you think are the best or most effective ways to help students with their school work and what are the least effective ways? What evidence do you have to support your evaluations? What does the teacher in the classroom think are the best ways? Do you agree? Why or why not? In what ways does the learning chapter assist you in your evaluation (give examples)? Do you think you can use the information on learning to improve your own studying and performance? Why or why not?

As a result of completing this reflection...

- I learned that...

- I learned this when...

- This learning matters because...

- In light of this learning, in the future I will...

Note. Reprinted from Service learning in psychology: Enhancing undergraduate education for the public good (p. 7I), by R. G. Bringle, R. M. Reeb, M. A. Brown, and A. I. Ruiz, 2016, Washington, DC: American Psychological Association. Reprinted with permission 


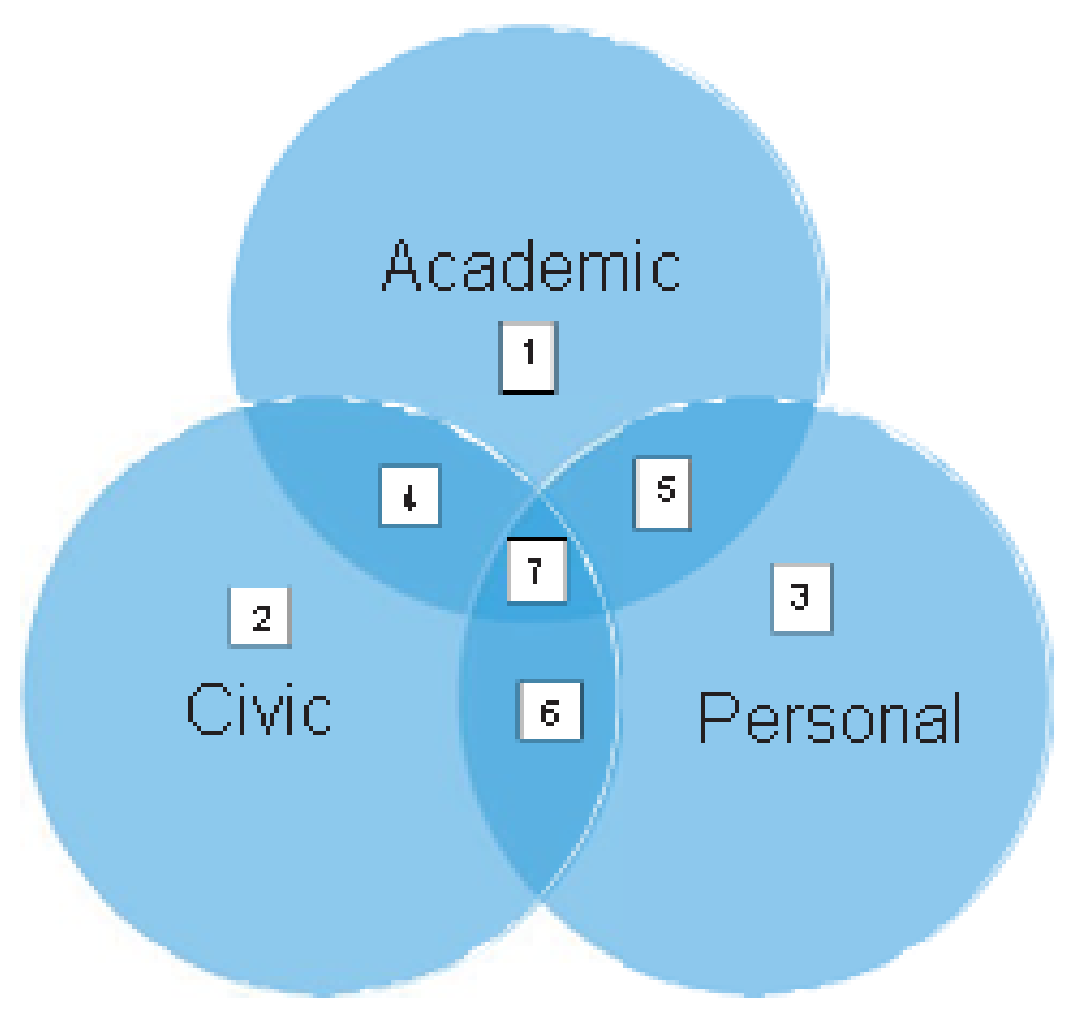

Figure 1. Learning Domains That Community Service Can Enhance.

Reprinted from Service learning in psychology: Enhancing undergraduate education for the public good (p.71), by R. G. Bringle, R. M. Reeb, M. A. Brown, and A. I. Ruiz, 2016, Washington, DC: American Psychological Association. Reprinted with permission.

1: Community service illustrates or informs a deeper understanding of an academic concept, theory, or research finding (e.g., students learn to differentiate the use of positive reinforcement, negative reinforcement, and punishment while they reflect on their observations of an elementary teacher's interaction with children in the classroom)

2: Community service contributes to civic growth in ways that are not necessarily related to the course content (e.g., students increase their knowledge of the nonprofit sector or better understand the dynamics of power and privilege, but these are not topics in the psychology course)

3: Community service contributes to personal growth in ways that are not necessarily related to the course content (e.g., students clarify personal values or career plans, but this is not a topic in the psychology course)

4: Community service connects academic content to civic learning (e.g., the course content covers intergroup contact theory and students learn better approaches for interacting with diverse groups in the community based on the theory and research presented on the intergroup contact theory as well as better learning the material on intergroup contact hypothesis) 
5: Community service connects academic content to personal growth (e.g., the course presents information on nonverbal communication and students analyze nonverbal cues at the site and become more aware of their nonverbal cues that they are displaying at the service site)

6: Community service contributes to civic learning and personal growth in ways that are not necessarily related to the course content (e.g., students become more knowledgeable about a community issue and more empathetic toward those persons associated with the community issue, but the community issue is not a specific topic in the psychology course)

7: Community service connects academic content to civic learning and personal growth (e.g., the course content on stigma influences how students conduct their service activities, the power of stigma in their interactions and the interactions of others, their awareness of their own attitudes and prejudices, and their understanding of the course material on stigma). 